Article

\title{
Inhibition of $\alpha$-Glucosidase, Acetylcholinesterase, and Nitric Oxide Production by Phytochemicals Isolated from Millettia speciosa-In Vitro and Molecular Docking Studies
}

\author{
Nguyen Ngoc Tuan ${ }^{1}$ D, Huong Nguyen Thi ${ }^{2,3}$, Chau Le Thi My ${ }^{4}$, Tang Xuan Hai ${ }^{5}$, Hieu Tran Trung ${ }^{2}$, \\ Anh Nguyen Thi Kim ${ }^{1}$, Thanh Nguyen Tan ${ }^{4}$, Tan Le Van ${ }^{6}{ }^{\mathbb{D}}$, Cuong Quoc Nguyen ${ }^{7}$, Quang De Tran ${ }^{7}$, \\ Ping-Chung Kuo ${ }^{8} \mathbb{D}$, Quang Le Dang ${ }^{9,10, * \mathbb{D}}$ and Tran Dinh Thang ${ }^{1, *}$
}

Citation: Tuan, N.N.; Thi, H.N.; My, C.L.T.; Hai, T.X.; Trung, H.T.; Kim,

A.N.T.; Tan, T.N.; Van, T.L.; Nguyen, C.Q.; Tran, Q.D.; et al. Inhibition of $\alpha$-Glucosidase, Acetylcholinesterase, and Nitric Oxide Production by Phytochemicals Isolated from Millettia speciosa-In Vitro and Molecular Docking Studies. Plants 2022, 11, 388. https://doi.org/ $10.3390 /$ plants 11030388

Academic Editor: Stefania Lamponi

Received: 9 December 2021

Accepted: 28 January 2022

Published: 30 January 2022

Publisher's Note: MDPI stays neutral with regard to jurisdictional claims in published maps and institutional affiliations.

Copyright: (c) 2022 by the authors. Licensee MDPI, Basel, Switzerland. This article is an open access article distributed under the terms and conditions of the Creative Commons Attribution (CC BY) license (https:// creativecommons.org/licenses/by/ $4.0 /)$.
1 Institute of Biotechnology and Food Technology, Industrial University of Ho Chi Minh City, Ho Chi Minh 71408, Vietnam; nguyenngoctuan@iuh.edu.vn (N.N.T.); nguyenthikimanh@iuh.edu.vn (A.N.T.K.)

2 School of Natural Sciences Education, Vinh University, Vinh City 43100, Nghean, Vietnam; nguyenthihuongtn@hdu.edu.vn (H.N.T.); trantrunghieu94tc@gmail.com (H.T.T.)

3 Faculty of Natural Sciences, Hong Duc University, Thanh Hoa 40100, Vietnam

4 School of Chemistry, Biology and Environment, Vinh University, Vinh City 43100, Nghean, Vietnam; lemychau83@gmail.com (C.L.T.M.); nguyentanthanhvn@gmail.com (T.N.T.)

5 Nghe An Obstetric \& Paediatric Hospital, Vinh City 43100, Nghean, Vietnam; bstangxuanhai@gmail.com

6 Faculty of Chemical Engineering, Industrial University of Ho Chi Minh City, Ho Chi Minh 71408, Vietnam; levantan@iuh.edu.vn

7 Department of Chemistry, College of Natural Sciences, Can Tho University, Can Tho 90000, Vietnam; ncquoc99@gmail.com (C.Q.N.); tqde@ctu.edu.vn (Q.D.T.)

8 School of Pharmacy, College of Medicine, National Cheng Kung University, Tainan 70101, Taiwan; z10502016@ncku.edu.tw

9 R\&D Center of Bioactive Compounds, Vietnam Institute of Industrial Chemistry, Hanoi 10000, Vietnam

10 Institute for Tropical Technology, Vietnam Academy of Science and Technology, Hanoi 10000, Vietnam

* Correspondence: ledangquang2011@gmail.com (Q.L.D.); thangtd@iuh.edu.vn (T.D.T.)

Abstract: The phytochemical constituents from the roots of Millettia speciosa were investigated by chromatographic isolation, and their chemical structures were characterized using the MS and NMR spectroscopic methods. A total of 10 compounds, including six triterpenoids, two flavonoids, and two phenolic compounds, were identified from the roots of $M$. speciosa. Out of the isolated compounds, eight showed inhibitory effects on NO production in lipopolysaccharide (LPS)-stimulated RAW 264.7 cells, with $\mathrm{IC}_{50}$ values ranging from 43.9 to $449.5 \mu \mathrm{g} / \mathrm{mL}$. Ursane-type triterpenes significantly suppressed NO production compared to the remaining compounds. In addition, these compounds also exhibited remarkable inhibitory effects on $\alpha$-glucosidase. Among the tested compounds, 4, 5, and 10 exhibited excellent $\alpha$-glucosidase inhibition, with $\mathrm{IC}_{50}$ values ranging from 1.1 to $2.2 \mu \mathrm{g} / \mathrm{mL}$. Almost all of the test compounds showed little or no acetylcholinesterase inhibition, except for 5, which showed moderate anti-acetylcholinesterase activity in vitro. The molecular docking study of $\alpha$-glucosidase inhibition by $\mathbf{3} \mathbf{- 5}$ and $\mathbf{1 0}$ was conducted to observe the interactions of these molecules with the enzyme. Compounds 4, 5, and 10 exhibited a better binding affinity toward the targeted receptor and the $\mathrm{H}$-bond interactions located at the entrance of the enzyme active site pocket in comparison to those of $\mathbf{3}$ and the positive control acarbose. Our findings evidence the pharmacological potential of this species and suggest that the phytochemicals derived from the roots of $M$. speciosa may be promising lead molecules for further studies on the development of anti-inflammatory and anti-diabetes drugs.

Keywords: Millettia speciosa; molecular docking; NO production; anti-glucosidase; anti-acetylcholinesterase 


\section{Introduction}

Millettia (Leguminosae) is a genus of about 200 species found in tropical and subtropical regions of Africa and Asia [1]. The chemical composition of Millettia is characterized by flavonoids, including chalcones, isoflavones, and triterpenoids [2,3]. Most of these plants are known for their folk medicinal applications. For example, M. speciosa and M. nitida var. hirsutissima are used in traditional medicine to alleviate dysmenorrhea, rheumatic, and paralysis [4,5]. Millettia griffoniana is employed orally for the treatment of boils, inflammation, amenorrhea, menopausal syndromes, sterility, and insect bites [6,7]. Millettia oblata has therapeutic uses for stomachache, cough, and swollen body, while M. usaramensis used as a remedy against snake bites [2].

Millettia speciosa Champ. (syn. Callerya speciosa) is a sub-shrub plant that is extensively used as a tonic and found primarily in the Chinese regions of Guangdong and Guangxi. Its roots are used to alleviate lumbago, as well as to strengthen bones and muscles [8-10]. It was commonly used as an edible plant in local regions, such as stewed chicken or soup, with the benefit of strengthening bones and muscles. Millettia speciosa widely grows in various provinces of Vietnam, including Tuyen Quang, Bac Can, Quang Ninh, Phu Tho, Bac Giang, Ha Noi, Lang Son, and Ha Nam [11]. Millettia speciosa roots have traditionally been used in Vietnamese traditional medicine to treat rheumatism, chronic bronchitis, and hepatitis [12]. Polysaccharides of M. speciosa have been considered to be the main active constituents and immunomodulatory agents for functional foods and traditional medicine [13]. A polysaccharide fraction (MSCP2) extracted from the roots of M. speciosa was reported to stimulate cytokine and NO production and suggested to be a promising immunomodulatory ingredient [14]. Six fractions of heteropolysaccharides derived from the roots of $M$. speciosa were effective at enhancing intestinal health, increasing immunerelated cytokine production, ameliorating body weight, and protecting immunological organs [13].

Previous phytochemical studies have reported that the root extract of $M$. speciosa contains various constituents, including alkaloids, oleanane-type triterpene saponin, flavonoids, isoflavones, rotenoids, lignans, chalcones, and phenolic glycosides [5,15-22]. Using UPLCQ-TOF-MS/MS, Dandan and Xianrui characterized 21 isoflavones and 4 isoflavanones in the roots of $M$. speciosa [23].

Docosanoic acid, tetracosane, octadecane, hexacosanoic acid, $\beta$-sitosterol acetate, $\beta$ sitosterol, syringin, maackiain, formononetin, $\psi$-baptigenin, rotundic acid, pedunculoside, and daucosterol were among the 13 phytochemicals discovered by Ding et al. [9]. An oleanane-type triterpenoid, $22 \beta$-acetoxy-3 $\beta, 24$-dihydroxy-12-oleanen-30-oic acid, together with medicarpin, maackiain, and $\beta$-sitosterol were identified from the ethyl acetate extract of the roots of M. speciosa growing in Vietnam [12]. However, the pharmaceutical properties of many constituents of this species were not fully described. There are also a few reports of the biological data for the secondary metabolites of Vietnamese M. speciosa. In our ongoing study of bioactive compounds from medicinal plants growing in Vietnam, we focused on the isolation of secondary metabolites from the roots of $M$. speciosa and characterized their chemical structures by the NMR and MS spectroscopic methods. The inhibition of anti-glucosidase, anti-acetylcholinesterase, and NO production by all isolated compounds was evaluated in vitro. In addition, a molecular docking study of $\alpha$-glucosidase inhibition by potent inhibitors was conducted to understand the interaction between the inhibitors and the enzyme.

\section{Results}

\subsection{Structural Characterization of the Isolated Compounds}

A total of 10 compounds, including six triterpenoids, two flavonoids, and two phenolic compounds were identified from the roots of M. speciosa (Figure 1). 


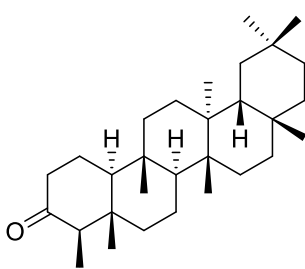

1

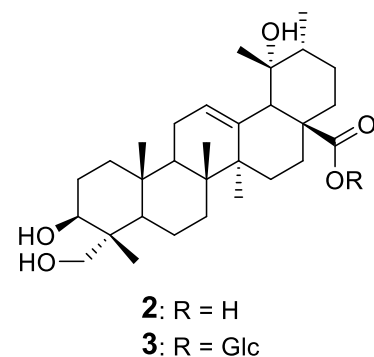

3: $R=G I C$

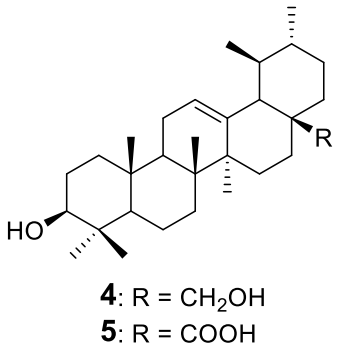

5: $\mathrm{R}=\mathrm{COOH}$
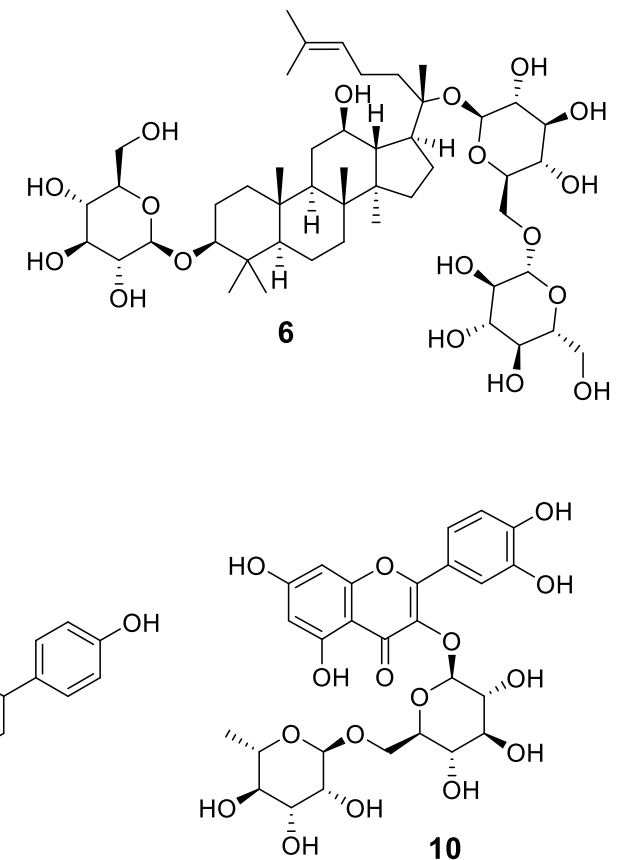<smiles>COc1ccc2c(c1)OCC1c3cc4c(cc3OC21)OCO4</smiles>

7<smiles>COc1cc(/C=C/CO)cc(OC)c1OC1OC(CO)C(O)C(O)C1O</smiles>

8<smiles>O=c1c(-c2ccc(O)cc2)coc2cc(OC3OC(CO)[C@H](O)[C@H](O)[C@H]3O)ccc12</smiles>

9

Figure 1. Chemical structures of the isolated compounds from the roots of Milletia speciosa. Compounds-1: friedelin; 2: rotundic acid; 3: pedunculoside; 4: uvaol; 5: ursolic acid; 6: gypenoside XVII; 7: pterocarpin; 8: syringin; 9: daidzin; 10: rutin.

Compound 6 was obtained as a white powder. The structure of Compound 6 was confirmed and verified by its HR-ESI-MS and 1D- and 2D-NMR (Data S1-Supplementary Materials). The ${ }^{1} \mathrm{H}-\mathrm{NMR}$ spectrum, the protons of 3-O-glucopyranosyl, and 20-O-glucopyranosyl moiety appeared at $4.33\left(1 \mathrm{H}, t, J=7.0 \mathrm{~Hz}, \mathrm{C}_{1^{\prime}}-\mathrm{H}\right), 4.59\left(1 \mathrm{H}, d, J=8.0 \mathrm{~Hz}, \mathrm{C}_{1^{\prime \prime}}-\mathrm{H}\right)$, and $4.32\left(1 \mathrm{H}, t, J=7.0 \mathrm{~Hz}, \mathrm{C}_{1^{\prime \prime \prime}}-\mathrm{H}\right)$, respectively. The anomeric proton signals showed that Compound $\mathbf{6}$ harbored three $\beta$-D-glucoses moieties. In addition, a comparison of the ${ }^{13} \mathrm{C}$-NMR spectrum of Compound $\mathbf{6}$ with that of gypenoside XVII suggests that Compound 6 is identical to 3-O-[ $\beta$-D-glucopyranosyl]-20-O-[ $\beta$-D-glucopyranosyl- $(6 \rightarrow 1)-\beta$-D-glucopyranosyl]-20(S)-protopanaxadiol [24].

Compound $\mathbf{8}$ was isolated as a white amorphous powder, and its mass spectral data suggest the molecular formula is $\mathrm{C}_{17} \mathrm{H}_{24} \mathrm{O}_{9}$. The ${ }^{1} \mathrm{H}-\mathrm{NMR}$ spectrum of $\mathbf{1}$ indicates the presence of a phenylpropanoid skeleton at $\delta_{\mathrm{H}} 6.48\left(1 \mathrm{H}, d, J=16.0 \mathrm{~Hz}, \mathrm{C}_{7}-\mathrm{H}\right), 6.35(1 \mathrm{H}$, $\left.d t, J=11.5 ; 5.0 \mathrm{~Hz}, \mathrm{C}_{8}-\mathrm{H}\right)$, and $4.30\left(2 \mathrm{H}, d d, J=11.5 ; 5.5 \mathrm{~Hz}, \mathrm{C}_{9}-\mathrm{H}\right)$, a glucose moiety at

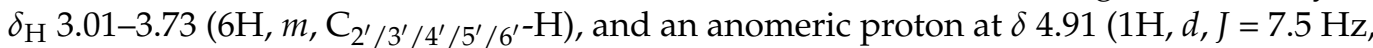
$\left.\mathrm{C}_{1^{\prime}}-\mathrm{H}\right)$. The coupling constant of $J=16.0 \mathrm{~Hz}$ is attributable to one pair of trans protons, which is the hallmark of cinnamic acid derivatives. $m$-substituted aromatic ring system signals were observed at $\delta_{\mathrm{H}} 6.72\left(2 \mathrm{H}, s, \mathrm{C}_{3} / 5-\mathrm{H}\right)$, and two methoxy groups were revealed at $3.76\left(6 \mathrm{H}, s, 2-\right.$ and $\left.6-\mathrm{OCH}_{3}\right)$. In the ${ }^{13} \mathrm{C}$ NMR data, a glucose moiety between $\delta_{\mathrm{C}} 60.9\left(\mathrm{C}_{6^{\prime \prime}}\right)$ and $76.6\left(\mathrm{C}_{5^{\prime \prime}}\right)$, and an anomeric carbon signal at $\delta_{\mathrm{C}} 104.5\left(\mathrm{C}_{1^{\prime \prime}}\right)$ were confirmed. The signal at $\delta_{\mathrm{C}} 56.4\left(\mathrm{C}_{2 / 6}-\mathrm{OCH}_{3}\right)$ indicates two methoxy carbons. Finally, the glucosyl $\mathrm{C}_{1^{\prime}}$-hydrogen atom $\left(\delta_{\mathrm{H}} 4.91\right)$ correlated with $\mathrm{C}_{1}\left(\delta_{\mathrm{C}} 133.9\right)$ of the phenylpropanoid unit in the HMBC spectrum. On the basis of the 1D- and 2D-NMR experiments, Compound 8 was assumed to be syringin [25].

Compound 9 was obtained as a yellow-brown powder. The ESI-MS of Compound 9 showed $m / z 417.2[\mathrm{M}+\mathrm{H}]^{+}$and was established to be $\mathrm{C}_{21} \mathrm{H}_{21} \mathrm{O}_{9}$. The signals of the aromatic protons were registered at $\delta_{\mathrm{H}} 7.41\left(2 \mathrm{H}, d, J=8.0 \mathrm{~Hz}, \mathrm{C}_{2^{\prime}} / 6^{\prime}-\mathrm{H}\right)$ and $6.82(2 \mathrm{H}, d$, $\left.J=8.0 \mathrm{~Hz}, \mathrm{C}_{3^{\prime} / 5^{\prime}}-\mathrm{H}\right)$. They also exhibited signals at $\delta_{\mathrm{H}} 8.05\left(1 \mathrm{H}, d, J=9.0 \mathrm{~Hz}, \mathrm{C}_{8}-\mathrm{H}\right)$, and $7.23\left(1 \mathrm{H}, J=2.0 \mathrm{~Hz}, \mathrm{C}_{6}-\mathrm{H}\right)$. In addition, a proton signal at $\mathrm{C}-5$ at $\delta_{\mathrm{H}} 7.15(1 \mathrm{H}, J=1.5 \mathrm{~Hz}$, $\left.\mathrm{C}_{5}-\mathrm{H}\right)$ was observed. In line with other studies on the ${ }^{13} \mathrm{C}$-NMR spectra of flavonoids, the carbon chemical shifts of the aglycone skeleton of Compound 9 were consistent with 
their assignments. The ${ }^{13} \mathrm{C}$ NMR chemical shift data of the glucose moiety of daidzin were clearly indicated by analysis of the ${ }^{13} \mathrm{C}$ NMR spectra, especially by the resonances for C- ${ }^{\prime \prime}$, $\mathrm{C}-2^{\prime \prime}, \mathrm{C}-3^{\prime \prime}, \mathrm{C}-4^{\prime \prime}, \mathrm{C}-5^{\prime \prime}$, and $\mathrm{C}-6^{\prime \prime}\left(\delta_{\mathrm{C}} 100.0,73.1,76.5,69.6,77.2\right.$, and 60.6, respectively). The location of the $\beta$-glucosyl unit was determined by ${ }^{3} \mathrm{~J}$-HMBC correlations between $\mathrm{H}-1^{\prime}$ and C-7. Thus, the structure of 9 was established as daidzin (daidzein-7-O- $\beta-\mathrm{D}-$ glucopyranoside) [26].

Compound 10 was obtained as a yellow powder. The ${ }^{1} \mathrm{H}-\mathrm{NMR}$ spectrum of Compound 10 showed the characteristic signals of the quercetin skeleton- $\delta_{\mathrm{H}} 6.26(d, J=2.1$ $\left.\mathrm{Hz}, \mathrm{C}_{6}-\mathrm{H}\right), 6.45\left(d, J=2.1 \mathrm{~Hz}, \mathrm{C}_{8}-\mathrm{H}\right), 7.68\left(d d, J=8.4,2.2 \mathrm{~Hz}, \mathrm{C}_{6}-\mathrm{H}\right), 6.92(d, J=8.4 \mathrm{~Hz}, \mathrm{H}-5)$, and $7.71(d, J=2.2 \mathrm{~Hz}, \mathrm{H}-2)$. In the HMBC spectrum, the rhamnosyl C1-hydrogen atom $\left(\delta_{\mathrm{H}} 4.56\right)$ correlated with the glucosyl $\mathrm{C}^{\prime}$ atom at $\delta \mathrm{C} 68.5$, indicating a rutinosyl moiety. Finally, the glucosyl $C 1^{\prime}$-hydrogen atom $\left(\delta_{\mathrm{H}} 5.15\right)$ correlated with $\mathrm{C} 3\left(\delta_{\mathrm{C}} 135.62\right)$ of the flavonoid unit in the HMBC spectrum. The analysis of the one- and two-dimensional ${ }^{1} \mathrm{H}-$ and ${ }^{13} \mathrm{C}-\mathrm{NMR}$ spectra of $\mathbf{1 0}$ and the comparison with the values found in the literature [27] led to the assignment of Compound $\mathbf{1 0}$ as quercetin-3-O-rutinoside (rutin).

\subsection{In Vitro Biological Activities of the Isolated Compounds from Millettia speciosa}

In this study, the in vitro anti-glucosidase, anti-AChE, and NO production inhibitory activities of the phytochemical constituents derived from the roots of $M$. speciosa growing in Vietnam were investigated.

A Griess assay was used to assess the inhibition of NO production in lipopolysaccharide (LPS)-stimulated RAW 264.7 cells by the isolated compounds at concentrations ranging from 0.8 to $500 \mu \mathrm{g} / \mathrm{mL}$. The results of the NO production assay for the tested compounds indicate that Compounds 2-6 displayed moderate activity, followed by Compounds 7, 8, and 10 (Figure 2).

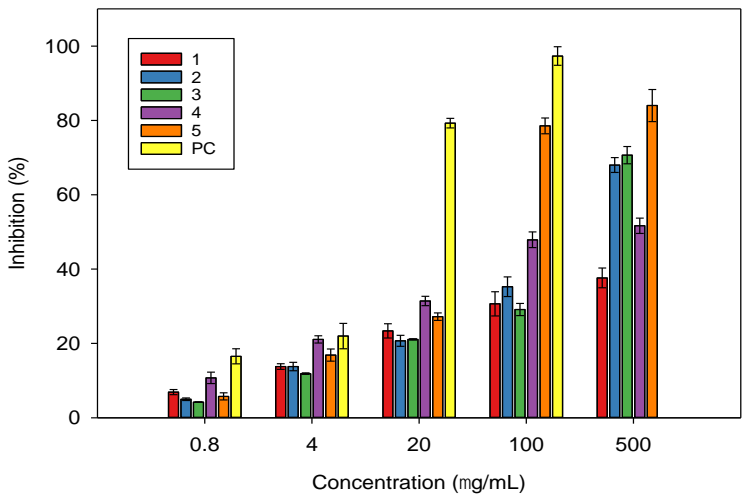

(A)

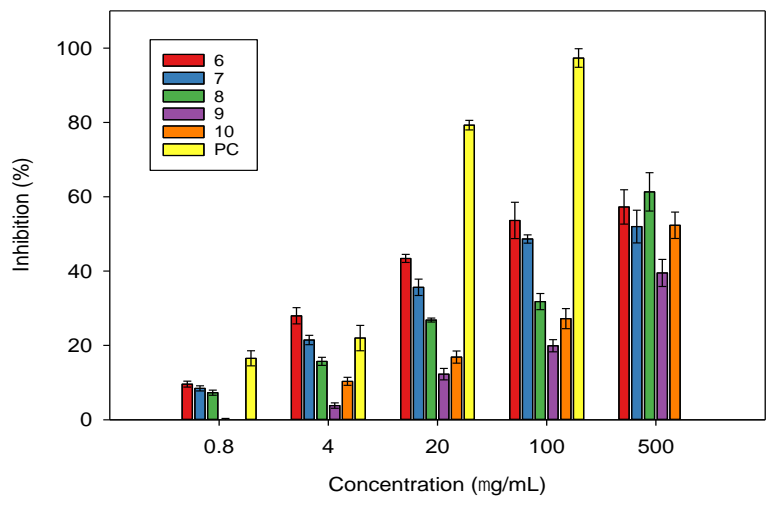

(B)

Figure 2. NO production inhibition of the isolated compounds from Millettia speciosa. Compounds(A): (1: friedelin; 2: rotundic acid; 3: pedunculoside; 4: uvaol; 5: ursolic acid); (B): (6: gypenoside XVII; 7: pterocarpin; 8: syringin; 9: daidzin; 10: rutin). The test compounds were evaluated for their inhibition at a concentration range of $0.8-500 \mu \mathrm{g} / \mathrm{mL}$. PC: positive control treated with L-NMMA at a concentration range of $0.8-100 \mu \mathrm{g} / \mathrm{mL}$.

Compounds 1 and 9 possessed weak activity for NO production; at $500 \mu \mathrm{g} / \mathrm{mL}$, their inhibitions for NO production were only 37.6\% (Figure 2A) and 39.5\% (Figure 2B), respectively. Ursolic acid (5) was found to be the best inhibitor for NO production. At $500 \mu \mathrm{g} / \mathrm{mL}$, this substance caused inhibition of $84.0 \%$ (Figure 2A); it also had the smallest $\mathrm{IC}_{50}$ of $43.9 \mu \mathrm{g} / \mathrm{mL}$ in comparison to the other constituents (Table 1). Gypenoside XVII (6) possessed an $\mathrm{IC}_{50}$ of $93.9 \mu \mathrm{g} / \mathrm{mL}$, followed by Compounds 7, 2, 4, and 3, with $\mathrm{IC}_{50}$ values of $228.9,241.33,246.49$, and $273.10 \mu \mathrm{g} / \mathrm{mL}$, respectively (Table 1 ). As expected in the 
experiment treated with L-NMMA, the positive control showed good inhibition for NO production, with an $\mathrm{IC}_{50}$ of $8.6 \mu \mathrm{g} / \mathrm{mL}$ (Table 1 ).

Table 1. Half-maximal inhibitory concentration $\left(\mathrm{IC}_{50}\right)$ for the inhibition of $\mathrm{NO}$ production by the isolated compounds from Millettia speciosa.

\begin{tabular}{cc}
\hline Compound $^{\mathbf{1}}$ & IC $_{\mathbf{5 0}}(\boldsymbol{\mu g} / \mathbf{m L})^{\mathbf{2}}$ \\
\hline $\mathbf{1}$ & $>500$ \\
$\mathbf{2}$ & $241.3 \pm 8.2$ \\
$\mathbf{3}$ & $273.1 \pm 8.2$ \\
$\mathbf{4}$ & $246.5 \pm 18.7$ \\
$\mathbf{5}$ & $43.9 \pm 3.7$ \\
$\mathbf{6}$ & $93.9 \pm 5.4$ \\
$\mathbf{7}$ & $228.9 \pm 18.6$ \\
$\mathbf{8}$ & $303.1 \pm 11.0$ \\
$\mathbf{9}$ & $>500$ \\
$\mathbf{1 0}$ & $449.5 \pm 5.2$ \\
PC & $8.6 \pm 0.9$
\end{tabular}

${ }^{1}$ Compounds-1: friedelin; 2: rotundic acid; 3: pedunculoside; 4: uvaol; 5: ursolic acid; 6: gypenoside XVII; 7: pterocarpin; 8: syringin; 9: daidzin; 10: rutin. PC: positive control with L-NMMA. ${ }^{2}$ Values are the means of three replicates \pm standard deviation $(\mathrm{SD})$.

In comparison, all of the test compounds did not show cytotoxicity against RAW 264.7 cells in the cell viability assay, except for Compound 5, which reduced the cell growth by $23.3 \%$ at $100 \mu \mathrm{g} / \mathrm{mL}$ (Figure 3 ).

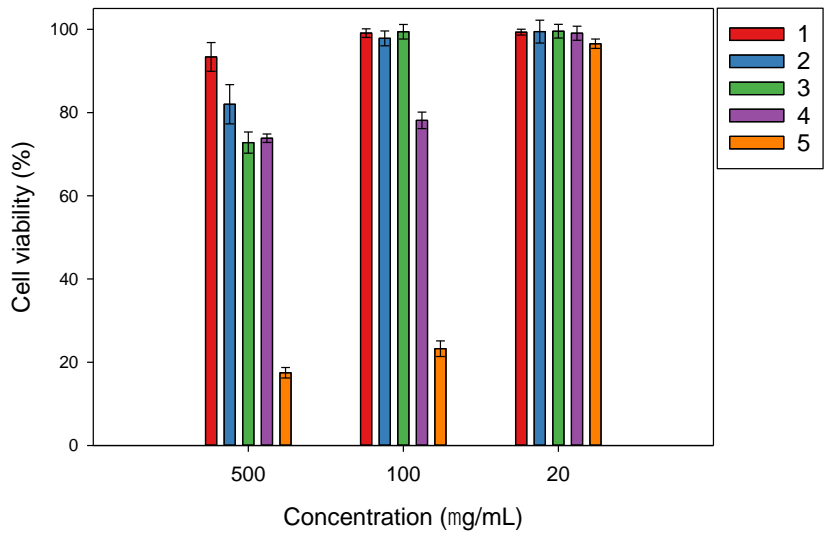

(A)

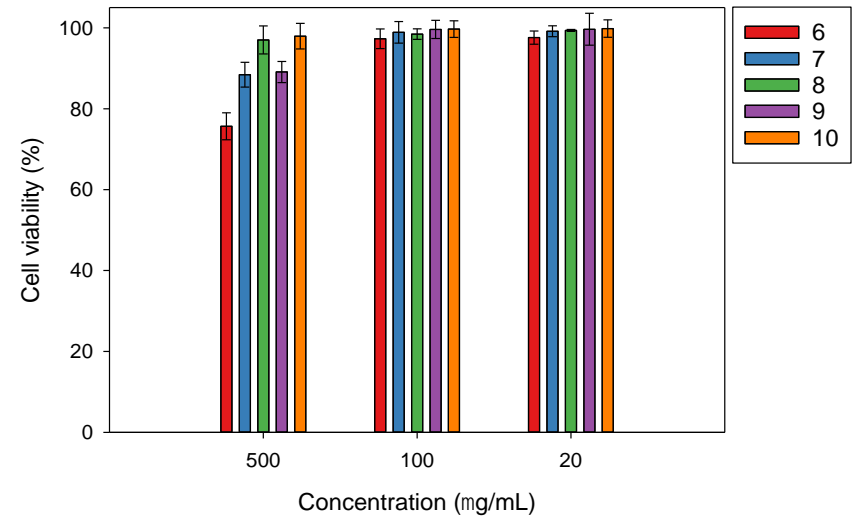

(B)

Figure 3. Viability of RAW264.7 cell line treated with the isolated compounds from Millettia speciosa. (A): (Compounds-1: friedelin; 2: rotundic acid; 3: pedunculoside; 4: uvaol; 5: ursolic acid); (B): (6: gypenoside XVII; 7: pterocarpin; 8: syringin; 9: daidzin; 10: rutin). The cells were incubated at $37^{\circ} \mathrm{C}$ under $\mathrm{CO}_{2}$ atmosphere.

The isolated compounds from $M$. speciose were tested for their inhibitory $\alpha$-glucosidase activity at a concentration range of 1-256 $\mu \mathrm{g} / \mathrm{mL}$. In particular, Compounds 4, 5, and 10 show the best $\alpha$-glucosidase inhibitions, with $\mathrm{IC}_{50}$ values of 2.0, 1.1, and $2.2 \mu \mathrm{g} / \mathrm{mL}$ (Table 2). At $256 \mu \mathrm{g} / \mathrm{mL}, \mathbf{4}, \mathbf{5}$, and 10 inhibited $\alpha$-glucosidase, with inhibitions percentages of 92.5, 99.0, and $85.0 \%$, respectively, even though 5 induced $91.5 \%$ inhibition for $\alpha$-glucosidase at $4 \mu \mathrm{g} / \mathrm{mL}$ (Table S1-Supplementary Materials). Compared to the positive control acarbose $\left(\mathrm{IC}_{50}=169.8 \mu \mathrm{g} / \mathrm{mL}\right)$, their activity was extremely significant. Compound 3 (pedunculoside) also caused inhibition of $60.5 \%$ for $\alpha$-glucosidase at $256.0 \mu \mathrm{g} / \mathrm{mL}$ and an $\mathrm{IC}_{50}$ of $184.9 \mu \mathrm{g} / \mathrm{mL}$ (Tables 2, S1-Supplementary Materials). Nevertheless, the remaining compounds, 1, 2, and 6-9, showed little to no inhibition for $\alpha$-glucosidase at the test concentration range. At $256.0 \mu \mathrm{g} / \mathrm{mL}$, the $\alpha$-glucosidase inhibitions of those compounds 
were determined to be $23.0 \%$ for $\mathbf{1}, 33.0 \%$ for $2,34.0 \%$ for $\mathbf{6}, 25.0 \%$ for $7,12.0 \%$ for 8 , and $22.0 \%$ for $\mathbf{9}$, respectively (Table S1-Supplementary Materials).

Table 2. Half-maximal inhibitory concentration $\left(\mathrm{IC}_{50}\right)$ for inhibition of $\alpha$-glucosidase by the isolated compounds from Millettia speciosa.

\begin{tabular}{ccc}
\hline Compound $^{2}$ & IC $_{\mathbf{5 0}}(\boldsymbol{\mu g} / \mathbf{m L})^{\mathbf{1}}$ & Fold Change \\
\hline $\mathbf{1}$ & $>256$ & $<0.663$ \\
$\mathbf{2}$ & $>256$ & $<0.663$ \\
$\mathbf{3}$ & $184.9 \pm 10.05$ & 0.918 \\
$\mathbf{4}$ & $1.96 \pm 0.09$ & 86.632 \\
$\mathbf{5}$ & $1.1 \pm 0.05$ & 154.363 \\
$\mathbf{6}$ & $>256$ & $<0.663$ \\
$\mathbf{7}$ & $>256$ & $<0.663$ \\
$\mathbf{8}$ & $>256$ & $<0.663$ \\
$\mathbf{9}$ & $>256$ & $<0.663$ \\
$\mathbf{1 0}$ & $2.2 \pm 0.09$ & 77.534 \\
Positive control $^{3}$ & $169.8 \pm 7.05$ & 1.000 \\
\hline
\end{tabular}

${ }^{1}$ Values are the means of three replicates \pm standard deviation (SD). ${ }^{2}$ Compounds-1: friedelin; 2 : rotundic acid 3: pedunculoside; 4: uvaol; 5: ursolic acid; 6: gypenoside XVII; 7: pterocarpin; 8: syringin; 9: daidzin; 10: rutin. ${ }^{3}$ Acarbose was used as a positive control in the evaluation of $\alpha$-glucosidase inhibition activity.

In the bioassay of $\mathrm{AChE}$ inhibition, rutin (10) was found to inhibit $\mathrm{AChE}$, with an $\mathrm{IC}_{50}$ of $256.0 \mu \mathrm{g} / \mathrm{mL}$, and Compound 5 was found to be the strongest inhibitor of AChE, with an $\mathrm{IC}_{50}$ of $8 \mu \mathrm{g} / \mathrm{mL}$; however, these inhibitions were much weaker compared to the positive control of donepezil $\left(\mathrm{IC}_{50}=0.025 \mu \mathrm{g} / \mathrm{mL}\right)$. The other compounds did not display any significant $\mathrm{AChE}$ inhibitions in the test concentration range (Table S2-Supplementary Materials).

\subsection{Docking Study for $\alpha$-Glucosidase Inhibition by Compounds $\mathbf{3}-\mathbf{5}$ and $\mathbf{1 0}$}

From the $\alpha$-glucosidase inhibition assay, Compounds 4, 5, and 10 displayed the strong anti-glucosidase efficacy, with 77.534 to 154.363 -fold greater than that of the positive control (acarbose), Compound 3 showed activity with a 0.918-fold change, and the remaining compounds exhibited fewer activities (lower than a 0.663 -fold change). Therefore, molecular docking studies were done to examine the interactions among $\alpha$-glucosidase with active substances. Compound 5 had a lower free binding energy $(-9.1 \mathrm{kcal} / \mathrm{mol})$ than Compounds $10(-8.7 \mathrm{kcal} / \mathrm{mol}), 4(-8.9 \mathrm{kcal} / \mathrm{mol})$, and $3(-5.0 \mathrm{kcal} / \mathrm{mol})$ according to the molecular docking results. The three Compounds 4, 5, and 10 had lower free binding energies than acarbose $(-7.9 \mathrm{kcal} / \mathrm{mol})$, indicating that the lower the free binding energy, the better the compound's affinity for the targeted receptor. As a result, the findings show that the active molecules bind to glucosidase more readily than acarbose (Figure 4 ). These findings are consistent with those acquired during an in vitro study. A detailed analysis of the pose of the docking is presented in Table 3.

The hydroxyl group $\left(\mathrm{C}_{3}-\mathrm{OH}\right)$ of 5 was located in the hydrophobic pocket, surrounded by the residues of Asp215 and Glu277, which form stable polar bonds (Figure 5A). Therefore, the active site was not occupied by water molecules. Before binding to the inhibitor, these water molecules catalyze the hydrolysis of the enzyme in the presence of glucose. Water molecules are also responsible for bridging the carboxylate groups of the catalytic Glu and Asp residues and participate in hydrolysis. The other water molecules are thought to form a water reservoir and provide water for subsequent hydrolytic events. Thus, the surrounding environment is primarily hydrophobic, which helps increase their mobility. These details were all mentioned in the study of Yamamoto et al. on the basis of the isomaltase structure from $S$. cerevisiae [28]. Similarly, the hydroxyl groups of $4\left(\mathrm{C}_{28}-\mathrm{OH}\right)$ and $10\left(\mathrm{C}_{7}-\mathrm{OH}\right)$ form stable bonds with Asp352, helping them to not be displaced by water molecules (Figure 5B,C). However, in the structure of Compound 3, the hydroxyl groups could not create polar interactions with the amino acids in the hydrophobic pocket (Figure 5D), thus suggesting that this compound could inhibit the function of the targeted 
enzymes at a higher concentration than the reference ligand (acarbose), which is consistent with the results of the in vitro anti- $\alpha$-glucosidase assay.

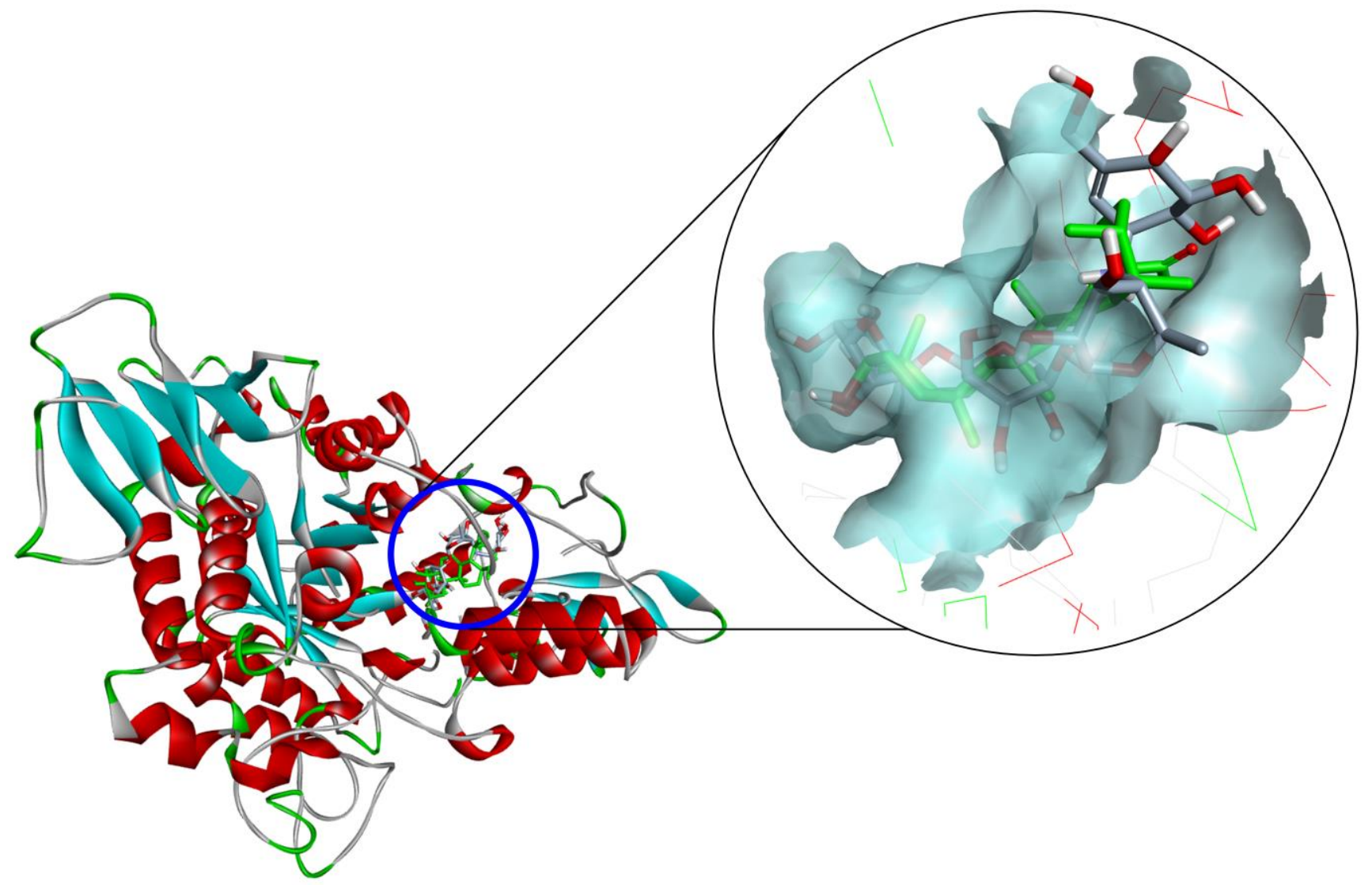

Figure 4. Compound 5 (green-most active) and acarbose (gray-control) at the active site of $\alpha$ glucosidase.

Table 3. Interaction residues of compounds obtained from molecular docking simulation.

\begin{tabular}{|c|c|}
\hline Compound ${ }^{1}$ & Hydrogen Bond Interacting Residues ${ }^{2}$ \\
\hline 3 & $\begin{array}{l}\text { Ser157, Tyr158 (unfavorable bump), Asp242, His280, Asp307 (unfavorable bump), } \\
\text { Pro312, Phe314, Arg315, Glu411 (unfavorable bump). }\end{array}$ \\
\hline 4 & Leu313 (unfavorable bump), Arg315, Asp352, Gln353. \\
\hline 5 & $\begin{array}{c}\text { Tyr158 (pi-alkyl), Asp215, Val216 (alkyl), Glu277, Phe303 (pi-alkyl), Arg315, } \\
\text { Glu411 (unfavorable bump). }\end{array}$ \\
\hline 10 & $\begin{array}{l}\text { Ser157, Ser240, Asp242, Phe303 (pi-pi stacked), Asp307 (pi-anion), Phe314, Ser311, } \\
\text { Agr315, Asp352, Gln353, Glu411, Arg442. }\end{array}$ \\
\hline Acarbose & $\begin{array}{c}\text { Asp69, Asp215, Ser240, Asp242, His280, Phe303, Pro312, Arg315 (unfavorable } \\
\text { bump), Arg442 (unfavorable bump). }\end{array}$ \\
\hline
\end{tabular}



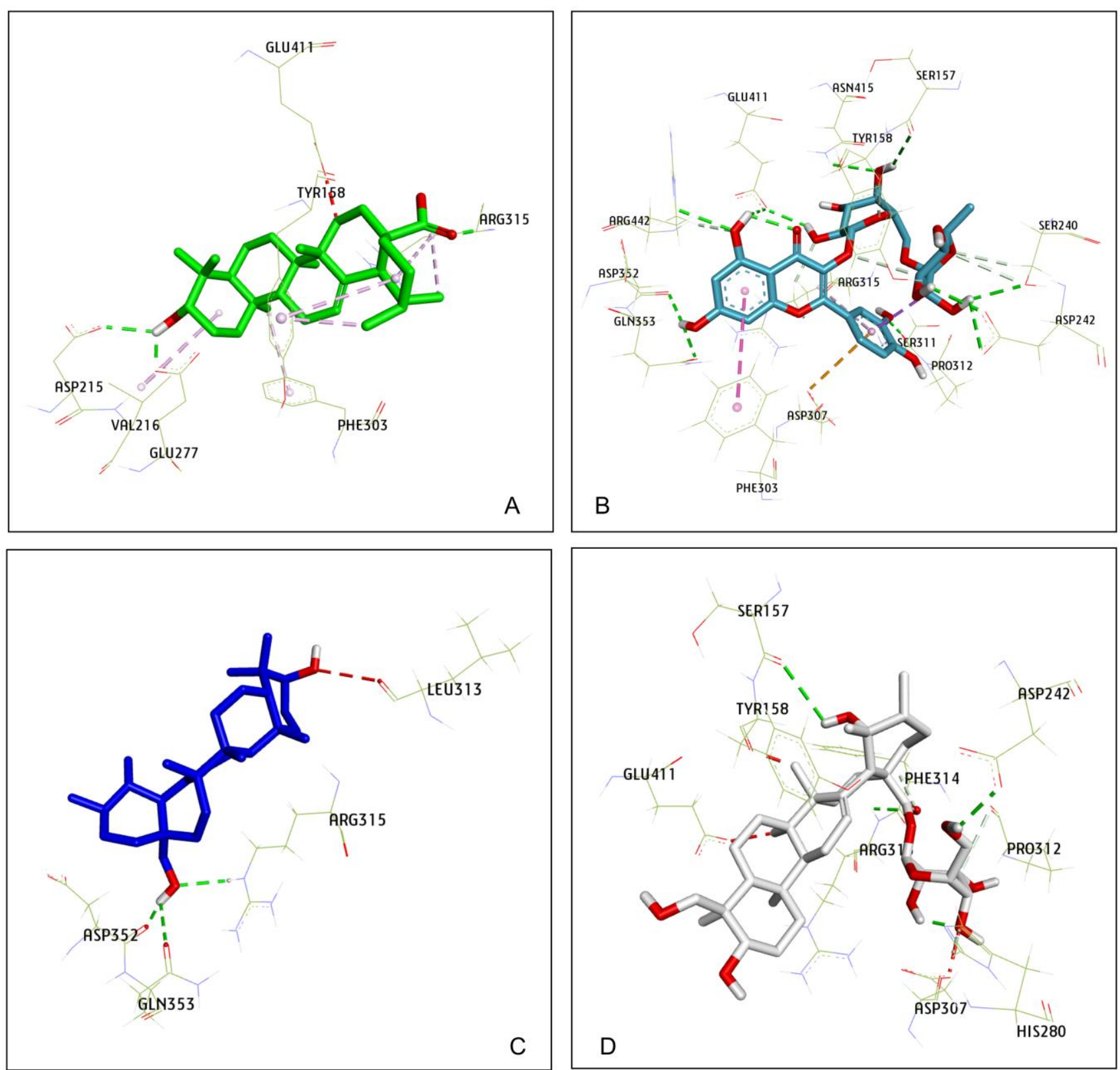

Figure 5. Compounds docked to the binding pocket of $\alpha$-glucosidase. (A) Compound 5-most active; (B) Compound 10; (C) Compound 4; (D) Compound 3-least active.

Another important hydrogen bond interaction was observed among the studied compounds and Tyr158, His280, and loop 310-315, which are located at the entrance of the active site pocket [28]. A detailed analysis showed that Compound 3 was involved in several H-bond interactions with Ser157, Tyr158, Asp242, His280, Asp307, Pro312, Phe314, Arg315, and Glu411. The residues of Arg315 and Gln353 were the main interactions between 4 and $\alpha$-glucosidase. Compound 5 created two pi-alkyl interactions with Tyr158 and Phe303, and one alkyl with Val216, which is different from 4, suggesting this interaction might lead to an enhancement in the inhibition activity of this compound. Compound 10 formed one pi-pi stacking (Phe303), one pi-anion (Asp307), and some H-bonds in the interactions with Ser157, Ser240, Asp242, Phe314 Ser311, Agr315, Gln353, Glu411, and Arg442 (Figure 5 and Table 3).

Compounds 4 and $\mathbf{5}$ were studied for the inhibition of human intestinal $\alpha$-glucosidase. The molecular docking results show that Compound 4 had a lower free binding energy 
$(-9.0 \mathrm{kcal} / \mathrm{mol})$ than Compound $5(-7.4 \mathrm{kcal} / \mathrm{mol})$. Two important interactions were observed between Compound 4 and the human intestinal $\alpha$-glucosidase enzyme; the side chains of Asp1157 formed a hydrogen bond with the $\mathrm{C}_{3}-\mathrm{OH}$ group, and $\mathrm{C}_{23}$ created a pi-sigma interaction with Trp1369. These interactions were also observed with acarbose in the study of Ren et al. [29]. An interaction with Trp1369 was only observed in Compound 5 at $\mathrm{C}_{29}$, and $\mathrm{C}_{28}$ (the acid group $\left(\mathrm{C}_{17}-\mathrm{COOH}\right)$ ) formed a hydrogen bond with Lys1460. Lys1460 acts as a base because it accepts protons from the acid group of 5 (Figure 6A).
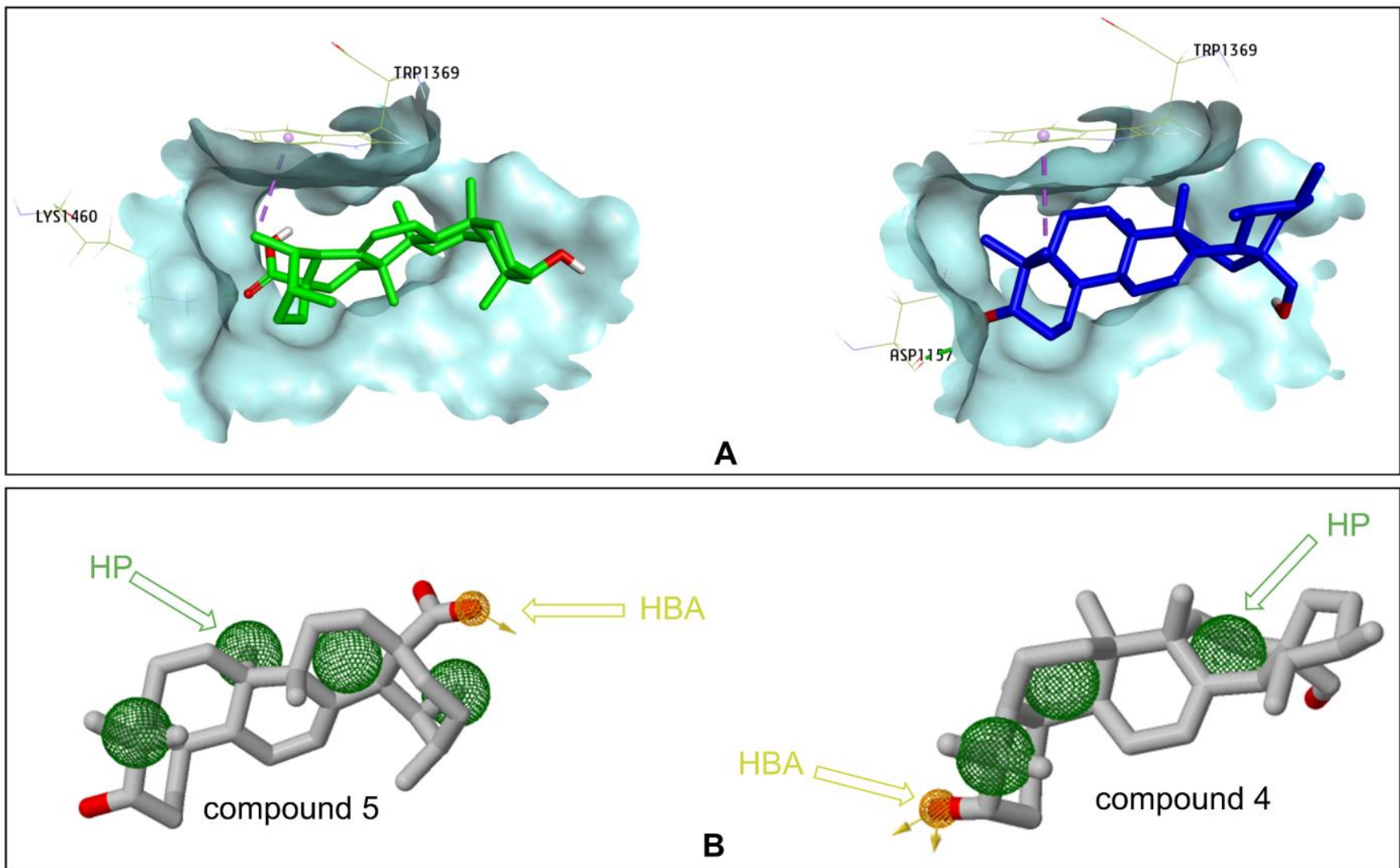

Figure 6. (A) Compound 4 (blue) and Compound 5 (green) in the binding site of human intestinal $\alpha$-glucosidase; (B) pharmacophore model. HBA: Hydrogen bond acceptors are depicted as yellowbrown arrows; HP: hydrophobic areas are depicted as green spheres.

The pharmacophore models on the interaction with human intestinal $\alpha$-glucosidase enzyme were generated using ZINCPharmer online [30]. It was also revealed that there were four hydrophobic areas (HPs) and one hydrogen bond acceptor (HBA) in Compound 5 , and the hydrogen bond acceptor was presented only on $\mathrm{C}_{17}-\mathrm{COOH}$. Compound 4 had three HPs and one HBA. The hydrogen bond acceptor was seen on $\mathrm{C}_{28}-\mathrm{OH}$ of Compound 4 (Figure 6B).

\section{Discussion}

The roots of $M$. speciosa have been known as traditional medicine materials and used for the treatment of joint pain, menoxenia, blood deficiency sallow, rheumatoid arthritis, amenorrhea, hepatitis, tuberculosis, and chronic bronchitis [15]. Several flavonoids and isoflavones, such as flavonoids naringenin, liquiritigenin, garbanzol, calycosin, and isoflavones 2'-hydroxybiochanin A, 7-hydroxy-6,4'-dimethoxyisoflavone, 2', $5^{\prime}, 7$-trihydroxy$4^{\prime}$-methoxyisoflavone, and 6-methoxycalopogonium isoflavones A, were reported to occur in the roots of this plant [8]. The polysaccharide fraction MSCP2 (molecular weight of $2.85 \times 10^{4} \mathrm{Da}$ ), composed of fucose, arabinose, galactose, glucose, and xylose, was found to possess immunomodulatory properties due to an enhancement in its pinocytic capacity 
and the levels of NO and cytokines in RAW 264.7 cells in vitro [14]. The ethanol extract of this material was observed to contain medicarpin and maackiain, two known pterocarpans that inhibited leukotriene secretion from RBL-2H3 cells and were toxic to HL-60 leukemia cells [18]. Two rotenoids, millettiaosas A-B, were isolated from the roots of $M$. speciosa and found to have moderate cytotoxicity against MCF-7, HCT-116, A549, and HepG-2 cell lines, with $\mathrm{IC}_{50}$ values ranging from 10 to $26 \mu \mathrm{M}$ in vitro [31]. In the present study, ten isolated compounds from this plant were identified to be friedelin, rotundic acid, pedunculoside, uvaol, ursolic acid, gypenoside XVII, pterocarpin, syringin, daidzin, and rutin. It is worth noting that the ursane-type triterpenes 4 and 5, gypenoside XVII (6), and pterocarpin (7) were identified for the first time in the roots of this species and displayed a remarkable inhibition for $\mathrm{NO}$ production. Ursolic acid was found to strongly suppress the NO production in lipopolysaccharide (LPS)-stimulated RAW 264.7 cells; however, it also caused moderate cytotoxicity against the cells. Ursolic acid has been known for its anti-cancer activity and multifunction effect on tumorigenesis, cell differentiation, and anti-angiogenic effect [32,33]. In a previous report by $\mathrm{Kim}$ et al., ursolic acid isolated from Phryma leptostachya var. asiatica was found to be effective on NO formation by $80.6 \%$ at a concentration of $40 \mu \mathrm{g} / \mathrm{mL}$ [34]. Even though Compound 5 (ursolic acid) seemed to be the best inhibitor for NO production in this study, it also caused cytotoxicity against RAW 264.7 macrophage cells at concentrations higher than $100 \mu \mathrm{g} / \mathrm{mL}$. As a result, Compound $6\left(\mathrm{IC}_{50}=93.9 \mu \mathrm{g} / \mathrm{mL}\right)$ was likely a more potent inhibitor and showed no cytotoxicity in comparison to 5 in the search of a promising candidate for anti-inflammatory drug development.

Among the four ursane-type triterpenes, Compounds 2-4 suppressed the NO production in RAW 264.7 macrophage cells without cytotoxicity and also displayed better inhibition compared to that of Compound 1, an oleanane-type triterpene occurring in the roots of $M$. speciosa.

The phenolic Compounds 7-10 were found in the extract of the roots of this plant; however, it seems that their inhibitory activity on NO production was less remarkable than those of ursane-type triterpenes (Table 1). Among the phenolic compounds, pterocarpin (7) showed an $\mathrm{IC}_{50}$ of $228.90 \mu \mathrm{g} / \mathrm{mL}$ and was, for the first time, found to be active against NO production. In contrast, Compounds 8 (syringin) and 10 (rutin) displayed insignificant effects on NO production in RAW 264.7 cells; the results are in the line with the discovery of [35], who found NO production was not blocked by syringin even at a high concentration of $1000 \mu \mathrm{M}$. This compound was described as an immunomodulator exerting an antiallergic effect rather than an anti-inflammatory effect. In addition, rutin was also found to mediate the NO synthesis in human umbilical vein endothelial cells by inducing eNOS mRNA expression, protein synthesis, and eNOS activity [36].

Diabetes is a metabolic epidemic disease and is the third cause of death for humans after cancer and cardiovascular disease. Enzyme $\alpha$-glucosidase is located on the epithelium of the small intestine and breaks down the ingested disaccharides into glucose. The inhibitors of $\alpha$-glucosidase inhibit the breakdown of starchy foods; this causes the suppression of postprandial hyperglycemia in the human body. Therefore, $\alpha$-glucosidase inhibitors have often been investigated and developed into drugs for type 2 diabetes treatments.

With regard to the anti- $\alpha$-glucosidase activity, it seems that the test compounds and the positive control acarbose fall in three groups. Group I consists of three strong active compounds, 4, 5, and 10, the activities of which were about 70 times higher than that of acarbose. Compound 3 and acarbose are classified into Group II, where Compound 3 moderately inhibits $\alpha$-glucosidase with a change of 0.918 -fold compared to acarbose. Group III consists of Compounds 1, 2, and 6-9, which showed no or poor anti-glucosidase efficacy. Compounds 4, 5, and 10 showed the best inhibition with $\mathrm{IC}_{50}$ values much lower than that of acarbose (2.0, 1.1, and 2.2 versus $169.8 \mu \mathrm{g} / \mathrm{mL}$, respectively). The anti- $\alpha$-glucosidase activity of rutin (10) was described by [37]; in their work, $\alpha$-glucosidase inhibition by rutin (a purchased sample) varied in the range of $10.6-52.6 \%$ at tested concentrations of 50-250 $\mu \mathrm{g} / \mathrm{mL}$. 
In addition, uvaol (4) and ursolic acid (5) are ursane-type triterpenes, and they were observed as the most potent inhibitors for $\alpha$-glucosidase. In the work, ursolic acid (5) showed the strongest $\alpha$-glucosidase inhibition; it showed an $\mathrm{IC}_{50}$ of $1.1 \mu \mathrm{g} / \mathrm{mL}$ and completely inhibited this enzyme $(91.5 \%)$ at $4 \mu \mathrm{g} / \mathrm{mL}$. These results are consistent with the data previously reported by Ding et al., in which oleanolic acid and ursolic acid possessed $\mathrm{IC}_{50}$ values of $(6.35 \pm 0.02) \times 10^{-6}$ and $(1.69 \pm 0.03) \times 10^{-5} \mathrm{~mol} / \mathrm{L}$ (equivalent to $7.71 \mu \mathrm{g} / \mathrm{mL}$ of ursolic acid), respectively, and ursolic acid inhibited $\alpha$-glucosidase in a non-competitive manner [38]. Zhang et al. also described the effectiveness of $\alpha$-glucosidase inhibition by pentacyclic triterpenes in the order of ursolic acid, corosolic acid, bentulinic acid, and oleanolic acid; ursolic acid was found to the best inhibitor, with an $\mathrm{IC}_{50}$ of $12.1 \mu \mathrm{M}$ (equivalent to $5.51 \mu \mathrm{g} / \mathrm{mL}$ of ursolic acid) [39]. The extracts of 14 Salvia species, which contain ursolic acid and oleanolic acid as primary constituents, were found to have a substantial inhibitory effect on $\alpha$-glucosidase, with $\mathrm{IC}_{50}$ values ranging from 17.6 to $173.0 \mu \mathrm{g} / \mathrm{mL}$ [40]. Uvaol and ursolic acid have the same skeleton of ursane-type triterpenoid and they differ from the substitutive group of $\mathrm{C}-28$, where uvaol is in the $\mathrm{CH}_{2} \mathrm{OH}$ group and ursolic acid is in the $\mathrm{COOH}$ group (Figure 1). Ursolic acid and uvaol isolated from Clinopodium taxifolium showed $\alpha$-glucosidase inhibition, with $\mathrm{IC}_{50}$ values of 72.7 and $521.0 \mu \mathrm{g} / \mathrm{mL}$, respectively [41]. According to Wang et al., ursolic acid (a commercial sample) and acarbose were tested against $\alpha$-glucosidase, and their $\mathrm{IC}_{50}$ values were determined to be $213 \mu \mathrm{g} / \mathrm{mL}$ for ursolic acid and $1160 \mu \mathrm{g} / \mathrm{mL}$ for acarbose [42]. In our study, the $\alpha$-glucosidase inhibitory activities of 2 and 3 derived from the roots of $M$. speciose were reported and evaluated for the first time. Interestingly, Compound $\mathbf{3}$ (pedunculoside) is also known as a ursane-type triterpenoid, but it showed moderate $\alpha$-glucosidase inhibitory activity (Table 2). Similar to the chemical structure of uvaol, Compounds 2 and 3 are derivatives of ursolic acid, with hydroxyl groups linked to $\mathrm{C}_{23}$ and $\mathrm{C}_{19}$; however, Compound 3 also has an ester linkage at $C_{28}$ with glucose. The difference in the structures of 2 and 3 may result in a reduction in $\alpha$-glucosidase enzymatic activities compared to those of 4 and $\mathbf{5}$ (Figure 1 and Table 3). Therefore, in this study, we also approached molecular docking to predict the orientation of Compound 3 and Group I at the active site of the $\alpha$-glucosidase enzyme. The main purpose was to clarify the mechanism and further strengthen our argument outlined above.

Molecular docking was utilized to predict the binding pose of the studied compounds in the active site of $\alpha$-glucosidase. Through molecular docking analysis with Autodock Vina, four compounds, 3-5 and 10, were found to insert into the hydrophobic pocket of $\alpha$-glucosidase and were surrounded by many polar amino acids. Ursolic acid (5) was found to mainly interact with six amino acid residues (Tyr158, Asp215, Val216, Glu277, Phe303, and Arg315). Three amino acids (Arg315, Asp352, and Gln353) formed H-bonds with uvaol (4), and the interactions were observed among the rutin (10) and the twelve residues. Compound 3 could not create polar interactions with the key amino acids deep at the bottom of the hydrophobic pocket as the above compounds. Therefore, the active site is still occupied by water molecules, so the hydrolytic process can occur at the beginning. However, Compound 3 shielded the entrance to the bag and prevented the supply of water for subsequent hydrolysis events. This may be the reason Compound $\mathbf{3}$ was less active than the other compounds. Interestingly, further research into the binding energies of two compounds to inhibit human intestinal $\alpha$-glucosidase revealed that Compound 4 had a lower free binding energy than Compound 5. Pharmacophore models on the interaction with human intestinal $\alpha$-glucosidase were generated using ZINCPharmer; the generated pharmacophore models could assist medicinal chemists in designing inhibitors against $\alpha$-glucosidase based on the structures of these two compounds. From the pharmacophore models, it is predicted that difference substituents at $C_{17}$ play the most important role in differentiating the activities of two compounds. Any systematic variations of substituents that change HBA and HP interactions can help in the discovery of molecules, with better biological effects than Compound 5 in the binding site of $\alpha$-glucosidase.

The present results in the molecular docking study of the ursane-type triterpenes show similarities with previous studies on $\alpha$-glucosidase targeting [37,43-45]. According 
to Dubey et al., a docking study of rutin was visualized by Discovery Studio, in which rutin demonstrated an inhibition constant of $67.62 \mu \mathrm{m}$ and binding energy of $-7.01 \mathrm{kcal} / \mathrm{mol}$ with $\alpha$-glucosidase (PDB ID: 3A4A) by non-covalent interaction [37].

Almost all of the isolated substances from the roots of $M$. specios $a$ exhibited low AChE inhibition, except Compound 5 showed moderate activity. In general, AChE inhibitors enhance cholinergic neurotransmission; therefore, the known phytochemicals of low toxicity would be safe for use in traditional medicine.

\section{Materials and Methods}

\subsection{Plant Materials}

The roots of M. speciosa (Figure S1-Supplementary Materials) were collected from October 2019 in Pumat National Park, Nghean province, Vietnam. The plant materials were identified by Dr. Quoc Binh Nguyen, Vietnam National Museum of Nature, Vietnam Academy of Science and Technology, Hanoi, Vietnam. The voucher samples (No. MS102019) were deposited in the same museum.

\subsection{General Procedures}

Electron-spray ionization-mass spectrometry (ESI-MS) spectra were measured on an Agilent 1100 LC-MSD-Trap-SL system (Agilent Technologies, Santa Clara, CA, USA). The Bruker Avance 500 NMR spectrometer was used to record ${ }^{1} \mathrm{H}-\mathrm{NMR},{ }^{13} \mathrm{C}-\mathrm{NMR}$, and DEPT spectra in $\mathrm{CDCl}_{3}$. Tetramethylsilane (TMS) served as an internal standard, and the chemical shifts were measured in parts per million (ppm) in comparison to the standard.

The $\alpha$-Glucosidase enzyme (CAS 9001-42-7) from Saccharomyces cerevisiae, $p$-nitrophenyl$\alpha$-D-glucopyranoside (CAS 3767-28-0), 4-nitrophenol (CAS 100-02-7), and dimethyl sulfoxide (DMSO, CAS 67-68-5) were purchased from Sigma-Aldrich (Burlington, MA, USA). Silica gel (40-63 $\mu \mathrm{m}, 60 \AA$, Merck, Darmstadt, Germany) was employed to use for open column chromatography (CC). Silica gel thin-layer chromatography (TLC) that was coated onto $\mathrm{F}_{254}$ aluminum plates was used for monitoring column separation and analyzing the purity of the isolated compounds.

\subsection{Isolation and Characterization of Phytochemical Constituents}

The roots of Millettia speciosa $(5.3 \mathrm{~kg})$ were extracted with ethanol at $60{ }^{\circ} \mathrm{C}(10 \mathrm{~L} \times 3)$ by ultrasound-assisted extraction (UAE), and total ethanol extract was evaporated under reduced pressure to yield the ethanol crude extract $(575 \mathrm{~g})$. Then, it was suspended in water and partitioned successively with $n$-hexane, ethyl acetate, and butanol to afford $n$-hexane extract (MSH-61 g), ethyl acetate extract (MSE-129 g), butanol extract (MSB-143 g), and a water-soluble fraction (MSW-121 g), respectively.

The MSH (61 g) was isolated by silica gel column chromatography (CC) (150 g, $150 \mathrm{~cm} \times 10 \mathrm{~cm}$ ) to collect five fractions (Frs. MSH1-MSH5). Fraction MSH5 was rechromatographed by CC $(80 \mathrm{~g}, 80 \times 1.5 \mathrm{~cm})$ eluted with a gradient of hexane-ethyl acetate $(15 / 1 ; 9 / 1 ; v / v)$ to yield friedelin $(1)(16.5 \mathrm{mg})$.

The MSE $(129 \mathrm{~g})$ was applied to CC $(300 \mathrm{~g}, 150 \mathrm{~cm} \times 10 \mathrm{~cm})$; then it was eluted with a mixture of chloroform-methanol with gradient $(100 / 0,20 / 1,10 / 1,5 / 1,2 / 1,1 / 1)$ to afford ten fractions (Frs. MSE1-MSE10). Fraction MSE2 (20.6 g) was separated by CC (80 g, $80 \times 1.5 \mathrm{~cm})$ and eluted with a mixture of hexane-ethyl acetate $(3 / 7 ; v / v)$ to afford ursolic acid (2) (12.8 mg). Fraction MSE3 (18.3 g) was separated by CC $(300 \mathrm{~g}, 80 \times 3 \mathrm{~cm})$ and eluted with a mixture of $n$-hexane-acetone $(15 / 1 ; v / v)$ to collect 3 fractions (MSE3.1-MSE3.3). The MSE3.2 was re-chromatographed by CC $(140 \mathrm{~g}, 80 \times 1.5 \mathrm{~cm})$ with a gradient of hexaneethyl acetate $(10 / 1 ; 7 / 1 ; v / v)$ to yield rotundic acid (3) $(14.2 \mathrm{mg})$. MSE3.3 was separated by CC $(50 \mathrm{~g}, 80 \mathrm{~cm} \times 1.5 \mathrm{~cm})$ and eluted with n-hexane-ethyl acetate (15:1) to collect uvaol (4) (14.5 mg). Fraction MSE4 (16.2 g) was subjected to column chromatography and eluted with n-hexane-ethyl acetate (15:1) to afford pterocarpin (7) $(21.5 \mathrm{mg})$. Fraction MSE6 (21.3 g) was subjected to CC $(100 \mathrm{~g}, 80 \times 1.5 \mathrm{~cm})$ to collect $(3 \beta, 4 \alpha)-3,19$,23-trihydroxy-urs-12-en-28-oic acid $\beta$-D-glucopyranosyl ester (5) (10.2 mg). 
The MSB (143 g) was applied to column chromatography on silica gel $(150 \mathrm{~cm} \times 10 \mathrm{~cm})$ and eluted with a $\mathrm{CHCl}_{3}-\mathrm{MeOH}$ mixture with a step gradient of $\mathrm{MeOH}$ to increase the polarity $(20: 1 ; 10: 1 ; 7: 1 ; 5: 1 ; 2: 1 ; v / v)$ to collect 8 fractions (Frs. MSB1-MSB8). Fraction MSB2 (2.9 g) was subjected to silica gel column chromatography $(300 \mathrm{~g}, 60 \times 3 \mathrm{~cm})$ and eluted with a mixture of chloroform and methanol $(15: 1,8: 1)$ to yield sinapyl alcohol 4O-glucoside (8) (52.0 mg). Fraction MSB3 was resolved by first using a Sephadex LH-20 column eluted with $\mathrm{CHCl}_{3}-\mathrm{MeOH}(1: 1)$ and then a silica gel column eluted with a mixture of $\mathrm{CHCl}_{3}-\mathrm{MeOH}(20: 1$ to 5:1) to obtain five minor fractions (MS3.1 to MSB3.5). The MSB3.4 was applied to silica gel column chromatography $\left(\mathrm{CHCl}_{3}: \mathrm{MeOH}=20: 1\right)$ and then thinlayer chromatography with $\left(\mathrm{CHCl}_{3}-\mathrm{MeOH}=20: 1\right)$ to produce the yellow powder denoted as daidzein-7-O- $\beta$-D-glucopyranoside (9) (23.0 mg). Fraction MSB4 was subjected to the preparative thin-layer chromatography (pTLC) (typical plate dimensions: $20 \mathrm{~cm} \times 20 \mathrm{~cm}$, $2.5 \mathrm{~mm} \mathrm{SiO}_{2}$ thickness) and eluted with a mixture of chloroform and methanol $(8: 1,6: 1)$ to produce rutin (10) $(57.0 \mathrm{mg})$. The purification of fraction MSB8 (12.6 g) was performed using an RP-18 column eluted with $\mathrm{MeOH}-\mathrm{H}_{2} \mathrm{O}(45: 55 ; v / v)$ to obtain four minor fractions (Frs. MSB8.1-MSB8.4). The minor fraction MSB8.2 (2.7 g) was isolated by preparative HPLC (ZORBAX SB-C18 (5 $\mu \mathrm{m}, 21.2 \times 100 \mathrm{~mm})$ with $\mathrm{MeOH}:-\mathrm{H}_{2} \mathrm{O}$ (55:45) for $10 \mathrm{~min}$ $\left(10 \mathrm{~mL} \mathrm{~min}^{-1}\right)$ to afford gypenoside XVII (6) $(6.2 \mathrm{mg})$.

\subsection{Structural Characterization of the Isolated Compounds}

The MS and NMR data of Compounds 1-10 isolated from the roots of Millettia speciosa are presented in Data S1 in the Supplementary Materials.

\subsection{In Vitro Evaluation of NO Production Inhibitory Activity of the Isolated Compounds}

The RAW 264.7 macrophage cell line was obtained from the Institute of Biology of the Vietnam Academy of Science and Technology and cultured in Dulbecco's Modified Eagle Medium (DMEM, Gibco, Thermo Fisher Scientific, Waltham, MA, USA) containing 2 mM of L-glutamine, $10 \mathrm{mM}$ of HEPES, and $1 \mathrm{mM}$ of sodium pyruvate. It was supplemented with $10 \%$ fetal bovine serum (FBS) and incubated at $37{ }^{\circ} \mathrm{C}$ in humidified air with $5 \% \mathrm{CO}_{2}$. RAW 264.7 macrophage cells in DMEM medium in 96-well plates were incubated for $24 \mathrm{~h}$, and NO production was stimulated by LPS $(1 \mu \mathrm{g} / \mathrm{mL})$. Next, $100 \mu \mathrm{L}$ of Griess reagent $(50 \mu \mathrm{L}$ of $1 \%(w / v)$ sulfanilamide in $5 \%(v / v)$ phosphoric acid and $50 \mu \mathrm{L}$ of $0.1 \%(w / v)$ $N$-1-naphthylethylenediamine dihydrochloride) was added, and it was incubated at room temperature for about $10 \mathrm{~min}$. The Griess Reagent System from Promega Cooperation (USA) was used to determine the presence of nitrite. The microplate reader was used to assess absorption at $540 \mathrm{~nm}$. N ${ }^{\mathrm{G}}$-Methyl-L-arginine acetate (L-NMMA) (Sigma) was used as a positive control at doses of $100,20,4$, and $0.8 \mathrm{~g} / \mathrm{mL}$. The $\mathrm{IC}_{50}$ values were calculated from non-linear regression analysis based on the dose-response curves using TableCurve 2Dv4 software. The experiments were repeated at least three times independently.

\subsection{Cell Viability Assay for the Evaluation of the Cytotoxicity of the Isolated Compounds}

The test compounds were diluted and added to 96-well microtiter plates with concentrations similar to those of the NO assay. The cells were diluted to a suitable cell density. One hundred eighty microliters of the cells were added to each well of the plate and incubated at $37^{\circ} \mathrm{C}, 5 \% \mathrm{CO}_{2}$ for $72 \mathrm{~h}$. After the incubation, $10 \mu \mathrm{L}$ of MTT solution $(5 \mathrm{mg} / \mathrm{mL})$ was added. After $4 \mathrm{~h}$, the MTT was removed and the formazan crystals were dissolved in $50 \mu \mathrm{L}$ of $100 \%$ DMSO. The OD was read by a microtiter plate reader at a wavelength of $540 \mathrm{~nm}$. Cell viability was calculated based on the formula as follows:

$$
\text { Cell viability }(\%)=[(\text { OD Sample }) /(\text { OD Control })] \times 100 \% \text {, }
$$

where OD is the optical density recorded at $540 \mathrm{~nm}$. 
4.7. In Vitro Bioassay for $\alpha$-Glucosidase Inhibition of the Isolated Compounds from the Roots of Milletia speciosa

The isolated compounds were tested for their $\alpha$-glucosidase inhibitory activity using the method previously reported by Ting et al. (2005) [46]. The test compounds were dissolved in dimethylsulfoxide (DMSO) to form stock solutions. $p$-NPG ( $p$-nitrophenyl $\alpha$-D-glucopyranoside) (Sigma-Aldrich) and $0.2 \mathrm{U} / \mathrm{mL}$ of $\alpha$-glucosidase from Saccharomyces cerevisiae (Sigma-Aldrich) were prepared in $100 \mathrm{mM}$ of potassium phosphate buffer with a $\mathrm{pH}$ of 6.8. UV absorption at $410 \mathrm{~nm}$ was measured using the BIOTEK machines. The halfmaximal inhibitory concentration $\left(\mathrm{IC}_{50}\right)$ values were calculated from non-linear regression analysis based on the dose-response curves.

\subsection{In Vitro Bioassay for Acetylcholinesterase Inhibition of the Isolated Compounds}

The acetylcholinesterase activity was determined by a colorimetric assay based on Ellman's methodology. The test compounds were prepared in a series of concentrations from 1 to $256 \mu \mathrm{g} / \mathrm{mL}$. They were dissolved in DMSO and then diluted with buffer (50 mM of Tris- $\mathrm{HCl}$, with a $\mathrm{pH}$ of 8 containing $0.1 \mathrm{M} \mathrm{NaCl}$ ), $0.1 \%$ bovine serum albumin (BSA), $25 \mu \mathrm{L}$ of acetylthiocholine iodide. The plate was incubated at $25{ }^{\circ} \mathrm{C}$ for $15 \mathrm{~min}$. The yellow 5-thio-2-nitrobenzoate anion was formed and could be detected at $405 \mathrm{~nm}$. Each assay was done in triplicate. The percentage of inhibition of AChE was determined by the following formula:

$$
\text { Inhibition }(\%)=[(\mathrm{OD} \text { of control }-\mathrm{OD} \text { of sample }) / \mathrm{OD} \text { of control }] \times 100 \text {. }
$$

\subsection{Molecular Docking Study for Anti- $\alpha$-Glucosidase Inhibition}

Since the crystallographic structure of Saccharomyces cerevisiae $\alpha$-glucosidase enzyme is not available in the Protein Data Bank (PDB), the three-dimensional structure of $\alpha$ glucosidase was built using homology modeling on the Swiss-Model website (https:/ / swissmodel.expasy.org/, accessed on 10 September 2021). The template structure was searched on NCBI protein BLAST to model the protein of interest. Swiss-Model suggested a crystal structure of isomaltase enzyme from S. cerevisiae (PDB ID: 3AJ7) with 72.4\% identity and $91 \%$ query coverage [28]. The stereochemical aspects of the model were inspected by checking the Ramachandran plot (see Supplementary Materials); it can be considered a liable model for further docking studies. This homology modeling was used to investigate the interactions of compounds with the active site of $\alpha$-glucosidase $[43,44,47]$. The crystal structure of human intestinal $\alpha$-glucosidase in a complex with acarbose inhibitor (PDB ID: 3TOP) was retrieved from the PDB. The three-dimensional structures of the selected compounds were created by Gaussview, and the energy minimization was carried out in Gaussian [48]. AutoDock Vina was employed to set up and perform the docking calculations by the PyRx program $[49,50]$. In this study, we performed the docking study assuming a rigid protein and considering the conformational space of the ligands to analyze the inductive effect of the hybrid compounds. In the docking analysis, the binding site was enclosed in a box with the number of grid points in $\mathrm{x} \times \mathrm{y} \times \mathrm{z}$ dimensions $(25 \AA \times 25 \AA \times 25 \AA)$. The center of the grid box was placed at $\mathrm{x}=22.2262, \mathrm{y}=-8.1477$, $\mathrm{z}=23.9431$ for Saccharomyces cerevisiae $\alpha$-glucosidase enzyme and $\mathrm{x}=22.2262, \mathrm{y}=-8.1477$, $\mathrm{z}=23.9431$ for the human intestinal $\alpha$-glucosidase. The outputs of the AutoDock Vina modeling studies were analyzed using Discovery Studio Visualizer.

\subsection{Statistical Analysis}

The assays were performed at least in triplicate and the values are expressed as the mean $\pm \mathrm{SD}$ (standard deviation). The half-maximal inhibitory concentration $\left(\mathrm{IC}_{50}\right)$ values were calculated from non-linear regression analysis based on the dose-response curves. 


\section{Conclusions}

Ursane-type triterpenes 4 and 5, gypenoside XVII (6), and pterocarpin (7) were isolated and identified from the roots of $M$. speciosa for the first time. The isolated ursane-type triterpenes 2-5 showed a remarkable inhibition for NO production in LPS-stimulated RAW 264.7 cells. In addition, Compounds 3 and acarbose inhibited $\alpha$-glucosidase at a similar potential level. Compounds 4, 5, and 10 showed the best $\alpha$-glucosidase inhibition, with $\mathrm{IC}_{50}$ values ranging from 1.1 to $2.2 \mu \mathrm{g} / \mathrm{mL}$. Through the molecular docking study of these inhibitors with $\alpha$-glucosidase, the interactions of 3-5 and $\mathbf{1 0}$ at the active site pocket were observed and provided an explanation for the in vitro results. These data suggest that the phytochemicals derived from the roots of $M$. speciosa may be promising lead molecules for further studies on the development of anti-inflammation and anti-diabetes drugs.

Supplementary Materials: The following are available online at https://www.mdpi.com/article/10 .3390/plants11030388/s1, Data S1: MS and NMR data of Compounds 1-10 isolated from Millettia speciosa. Figure S1: Image of the roots of Millettia speciosa, Figure S2: Isolation scheme of isolated Compounds 1-10 from the fruits of Millettia speciosa, Figure S3: Ramachandran plot analysis of the structure of Saccharomyces cerevisiae $\alpha$-glucosidase model, Figure S4: 2D binding model of Compound 3 in the active site of Saccharomyces cerevisiae $\alpha$-glucosidase enzyme; Figure S5: 2D binding model of Compound 4 in the active site of Saccharomyces cerevisiae $\alpha$-glucosidase enzyme; Figure S6: 2D binding model of Compound 5 in the active site of Saccharomyces cerevisiae $\alpha$-glucosidase enzyme; Figure S7: $2 \mathrm{D}$ binding model of Compound $\mathbf{1 0}$ in the active site of Saccharomyces cerevisiae $\alpha$-glucosidase enzyme; Figure S8: 2D binding model of Compound 4 in the active site of human intestinal $\alpha$-glucosidase enzyme; Figure S9: 2D binding model of Compound 5 in the active site of human intestinal $\alpha$ glucosidase enzyme. Table S1: $\alpha$-Glucosidase inhibition of by the isolated compounds from Millettia speciosa. Table S2: Half-maximal inhibitory concentration $\left(\mathrm{IC}_{50}\right)$ values for acetylcholinesterase inhibition by the isolated compounds from Millettia speciose.

Author Contributions: N.N.T., T.D.T., C.L.T.M. and Q.L.D.: conceptualization, methodology, and supervision; N.N.T., H.N.T., H.T.T., T.N.T. and T.D.T.: extraction, purification, and structure identification for isolated compounds; T.X.H., A.N.T.K., C.L.T.M., Q.D.T. and Q.L.D.: biological data analysis; C.Q.N., Q.D.T., N.N.T. and P.-C.K.: docking study; N.N.T., T.L.V., T.N.T., C.Q.N., Q.D.T., P.-C.K., Q.L.D. and T.D.T.: writing-original draft preparation and editing. All authors have read and agreed to the published version of the manuscript.

Funding: The authors gratefully acknowledge grants from the Ministry of Education and Training (MOET) Vietnam (No. B2020-DHV-02) for the financial support for the present study.

Data Availability Statement: The data used to support the findings of this study are included in the article.

Conflicts of Interest: The authors declare no conflict of interest.

\section{References}

1. Banzouzi, J.T.; Prost, A.; Rajemiarimiraho, M.; Ongoka, P. Traditional Uses of the African Millettia Species (Fabaceae). Int. J. Bot. 2008, 4, 406-420. [CrossRef]

2. Deyou, T.; Gumula, I.; Pang, F.; Gruhonjic, A.; Mumo, M.; Holleran, J.; Duffy, S.; Fitzpatrick, P.A.; Heydenreich, M.; Landberg, G.; et al. Rotenoids, Flavonoids, and Chalcones from the Root Bark of Millettia Usaramensis. J. Nat. Prod. 2015, 78, 2932-2939. [CrossRef] [PubMed]

3. Derese, S.; Barasa, L.; Akala, H.M.; Yusuf, A.O.; Kamau, E.; Heydenreich, M.; Yenesew, A. 4'-Prenyloxyderrone from the Stem Bark of Millettia Oblata Ssp. Teitensis and the Antiplasmodial Activities of Isoflavones from Some Millettia Species. Phytochem. Lett. 2014, 8, 69-72. [CrossRef]

4. Cheng, J.; Zhao, Y.-Y.; Wang, B.; Qiao, L.; Liang, H. Flavonoids from Millettia Nitida Var. Hirsutissima. Chem. Pharm. Bull. 2005, 53, 419-421. [CrossRef] [PubMed]

5. Yin, T.; Liang, H.; Wang, B.; Zhao, Y. A New Flavonol Glycoside from Millettia Speciosa. Fitoterapia 2010, 81, 274-275. [CrossRef] [PubMed]

6. Yankep, E.; Njamen, D.; Fotsing, M.T.; Fomum, Z.T.; Mbanya, J.-C.; Giner, R.M.; Recio, M.C.; Máñez, S.; Ríos, J.L. Griffonianone D, an Isoflavone with Anti-Inflammatory Activity from the Root Bark of Millettia Griffoniana. J. Nat. Prod. 2003, 66, 1288-1290. [CrossRef] [PubMed] 
7. Ketcha Wanda, G.J.M.; Njamen, D.; Yankep, E.; Tagatsing Fotsing, M.; Tanee Fomum, Z.; Wober, J.; Starcke, S.; Zierau, O.; Vollmer, G. Estrogenic Properties of Isoflavones Derived from Millettia Griffoniana. Phytomedicine 2006, 13, 139-145. [CrossRef]

8. Fu, M.; Xiao, G.; Xu, Y.; Wu, J.; Chen, Y.; Qiu, S.-X. Chemical Constituents from Roots of Millettia Speciosa. Chin. Herb. Med. 2016, 8, 385-389. [CrossRef]

9. Ding, P.; Qiu, J.; Ying, G.; Dai, L. Chemical Constituents of Millettia Speciosa. Chin. Herb. Med. 2014, 6, 332-334. [CrossRef]

10. Editorial Board of Chinese Materia Medica in Guangdong; Guangdong Science and Technology Press: Guangzhou, China, 1991.

11. Vo, C.V. A Dictionary of the Medicinal Plants of Vietnam; Y Hoc Publisher: Ha Noi, Vietnam, 2012.

12. Dao, D.T.; Nguyen, T.T.; Nguyen, T.H.A.; Dong, T.K.C.; Nguyen, T.T.M.; Tran, D.Q.; Nguyen, H.S.; Trinh, T.T. A New Oleanane Triterpenoid from the Roots of Callerya Speciosa. Lett. Org. Chem. 2020, 17, 388-392.

13. Chen, X.; Sun, W.; Xu, B.; Wu, E.; Cui, Y.; Hao, K.; Zhang, G.; Zhou, C.; Xu, Y.; Li, J.; et al. Polysaccharides From the Roots of Millettia Speciosa Champ Modulate Gut Health and Ameliorate Cyclophosphamide-Induced Intestinal Injury and Immunosuppression. Front. Immunol. 2021, 12, 766296. [CrossRef] [PubMed]

14. Huang, Z.; Zeng, Y.-J.; Chen, X.; Luo, S.-Y.; Pu, L.; Li, F.-Z.; Zong, M.-H.; Lou, W.-Y. A Novel Polysaccharide from the Roots of Millettia Speciosa Champ: Preparation, Structural Characterization and Immunomodulatory Activity. Int. J. Biol. Macromol. 2020, 145, 547-557. [CrossRef] [PubMed]

15. Jena, R.; Rath, D.; Rout, S.S.; Kar, D.M. A Review on Genus Millettia: Traditional Uses, Phytochemicals and Pharmacological Activities. Saudi Pharm. J. 2020, 28, 1686-1703. [CrossRef]

16. Zhao, Z.; Liu, P.; Ma, S.; Wang, S.; Ang, L.; Liu, J.; Wang, M. Botanical Characteristics, Chemical and Nutritional Composition and Pharmacological and Toxicological Effects of Medicinal and Edible Plant Millettia Speciosa Champ. Food Sci. 2017, 9, 293-306. [CrossRef]

17. Zhang, M.; Cui, C.; Lin, Y.; Cai, J. Ameliorating Effect on Glycolipid Metabolism and Chemical Profile of Millettia Speciosa Champ. Extract. J. Ethnopharmacol. 2021, 279, 114360. [CrossRef]

18. Uchiyama, T.; Furukawa, M.; Isobe, S. New Oleanane-Type Triterpene Saponins from Millettia Speciosa. Heterocycles 2003, 60, 655-661.

19. Wang, C.H.; Wang, Y.; Wang, G.C.; Ya, J.; Zhang, X.; Ye, W.C. Chemical Constituents from Roots of Millettia Speciosa. Chin. Tradit. Herb. Drugs 2008, 39, 972-975.

20. Yin, T.; Tu, G.; Zhang, Q.; Wang, B.; Zhao, Y. Three New Phenolic Glycosides from the Caulis of Millettia Speciosa. Magn. Reson. Chem. 2008, 46, 387-391. [CrossRef]

21. Zhang, H.; Ding, G.; Li, R.; Wei, J.; Zou, Z. Isolation, Identification and Quantitative Analysis of Hypaphorine in the Root of Millettia Speciosa Champ. Chin. J. Pharm. Anal. 2011, 31, 1024-1026.

22. Zong, X.-K.; Lai, F.-L.; Wang, Z.-N.; Wang, J.-R. Studies on chemical constituents of root of Millettia speciosa. Zhong Yao Cai 2009, 32, 520-521.

23. Dandan, Y.; Xianrui, L. Characterization and Identification of Isoflavonoids in the Roots of Millettia Speciosa Champ. by UPLC-Q-TOF-MS/MS. Curr. Pharm. Anal. 2019, 15, 580-591.

24. Cheng, L.-Q.; Na, J.-R.; Kim, M.K.; Bang, M.-H.; Yang, D.-C. Microbial Conversion of Ginsenoside Rb1 to Minor Ginsenoside F2 and Gypenoside XVII by Intrasporangium Sp. GS603 Isolated from Soil. J. Microbiol. Biotechnol. 2007, 17, 1937-1943. [PubMed]

25. Wang, C.; Chao, Z.; Sun, W.; Wu, X.; Ito, Y. Isolation of Five Glycosides from the Barks of Ilex Rotunda by High-Speed Counter-Current Chromatography. J. Liq. Chromatogr. Relat. Technol. 2014, 37, 2363-2376. [CrossRef] [PubMed]

26. Fedoreyev, S.A.; Bulgakov, V.P.; Grishchenko, O.V.; Veselova, M.V.; Krivoschekova, O.E.; Kulesh, N.I.; Denisenko, V.A.; Tchernoded, G.K.; Zhuravlev, Y.N. Isoflavonoid Composition of a Callus Culture of the Relict Tree Maackia Amurensis Rupr. et Maxim. J. Agric. Food Chem. 2008, 56, 7023-7031. [CrossRef] [PubMed]

27. Zor, M.; Aydin, S.; Güner, N.D.; Başaran, N.; Başaran, A.A. Antigenotoxic Properties of Paliurus Spina-Christi Mill Fruits and Their Active Compounds. BMC Complementary Altern. Med. 2017, 17, 229. [CrossRef] [PubMed]

28. Yamamoto, K.; Miyake, H.; Kusunoki, M.; Osaki, S. Crystal Structures of Isomaltase from Saccharomyces Cerevisiae and in Complex with Its Competitive Inhibitor Maltose. FEBS J. 2010, 277, 4205-4214. [CrossRef] [PubMed]

29. Ren, L.; Qin, X.; Cao, X.; Wang, L.; Bai, F.; Bai, G.; Shen, Y. Structural Insight into Substrate Specificity of Human Intestinal Maltase-Glucoamylase. Protein Cell 2011, 2, 827-836. [CrossRef] [PubMed]

30. Koes, D.R.; Camacho, C.J. ZINCPharmer: Pharmacophore Search of the ZINC Database. Nucleic Acids Res. 2012, 40, W409-W414 [CrossRef]

31. Chen, D.-L.; Liu, Y.-Y.; Ma, G.-X.; Zhu, N.-L.; Wu, H.-F.; Wang, D.-L.; Xu, X.-D. Two New Rotenoids from the Roots of Millettia Speciosa. Phytochem. Lett. 2015, 12, 196-199. [CrossRef]

32. You, H.J.; Choi, C.Y.; Kim, J.Y.; Park, S.J.; Hahm, K.-S.; Jeong, H.G. Ursolic Acid Enhances Nitric Oxide and Tumor Necrosis Factor- $\alpha$ Production via Nuclear Factor-KB Activation in the Resting Macrophages. FEBS Lett. 2001, 509, 156-160. [CrossRef]

33. Lee, A.-W.; Chen, T.-L.; Shih, C.-M.; Huang, C.-Y.; Tsao, N.-W.; Chang, N.-C.; Chen, Y.-H.; Fong, T.-H.; Lin, F.-Y. Ursolic Acid Induces Allograft Inflammatory Factor-1 Expression via a Nitric Oxide-Related Mechanism and Increases Neovascularization. $J$. Agric. Food Chem. 2010, 58, 12941-12949. [CrossRef] [PubMed]

34. Kim, D.; Lee, S.K.; Park, K.-S.; Kwon, N.-Y.; Park, H.-J. Isolation of Constituents with Nitric Oxide Synthase Inhibition Activity from Phryma leptostachya var. asiatica. Nat. Prod. Sci. 2019, 25, 34-37. [CrossRef] 
35. Cho, J.Y.; Nam, K.H.; Kim, A.R.; Park, J.; Yoo, E.S.; Baik, K.U.; Yu, Y.H.; Park, M.H. In-Vitro and in-Vivo Immunomodulatory Effects of Syringin. J. Pharm. Pharmacol. 2001, 53, 1287-1294. [CrossRef] [PubMed]

36. Ugusman, A.; Zakaria, Z.; Chua, K.H.; Megat Mohd Nordin, N.A.; Abdullah Mahdy, Z. Role of Rutin on Nitric Oxide Synthesis in Human Umbilical Vein Endothelial Cells. Sci. World J. 2014, 2014, e169370. [CrossRef] [PubMed]

37. Dubey, S.; Ganeshpurkar, A.; Ganeshpurkar, A.; Bansal, D.; Dubey, N. Glycolytic Enzyme Inhibitory and Antiglycation Potential of Rutin. Future J. Pharm. Sci. 2017, 3, 158-162. [CrossRef]

38. Ding, H.; Hu, X.; Xu, X.; Zhang, G.; Gong, D. Inhibitory Mechanism of Two Allosteric Inhibitors, Oleanolic Acid and Ursolic Acid on $\alpha$-Glucosidase. Int. J. Biol. Macromol. 2018, 107, 1844-1855. [CrossRef] [PubMed]

39. Zhang, B.-W.; Xing, Y.; Wen, C.; Yu, X.-X.; Sun, W.-L.; Xiu, Z.-L.; Dong, Y.-S. Pentacyclic Triterpenes as $\alpha$-Glucosidase and $\alpha$-Amylase Inhibitors: Structure-Activity Relationships and the Synergism with Acarbose. Bioorg. Med. Chem. Lett. 2017, 27, 5065-5070. [CrossRef] [PubMed]

40. Kalaycıoğlu, Z.; Uzaşçı, S.; Dirmenci, T.; Erim, F.B. $\alpha$-Glucosidase Enzyme Inhibitory Effects and Ursolic and Oleanolic Acid Contents of Fourteen Anatolian Salvia Species. J. Pharm. Biomed. Anal. 2018, 155, 284-287. [CrossRef]

41. Morocho, V.; Valle, A.; García, J.; Gilardoni, G.; Cartuche, L.; Suárez, A.I. $\alpha$-Glucosidase Inhibition and Antibacterial Activity of Secondary Metabolites from the Ecuadorian Species Clinopodium Taxifolium (Kunth) Govaerts. Molecules 2018, $23,146$. [CrossRef]

42. Wang, J.; Zhao, J.; Yan, Y.; Liu, D.; Wang, C.; Wang, H. Inhibition of Glycosidase by Ursolic Acid: In Vitro, in Vivo and in Silico Study. J. Sci. Food Agric. 2020, 100, 986-994. [CrossRef]

43. Peytam, F.; Takalloobanafshi, G.; Saadattalab, T.; Norouzbahari, M.; Emamgholipour, Z.; Moghimi, S.; Firoozpour, L.; Bijanzadeh H.R.; Faramarzi, M.A.; Mojtabavi, S.; et al. Design, Synthesis, Molecular Docking, and in Vitro $\alpha$-Glucosidase Inhibitory Activities of Novel 3-Amino-2,4-Diarylbenzo[4,5]Imidazo[1,2-a]Pyrimidines against Yeast and Rat $\alpha$-Glucosidase. Sci. Rep. 2021, $11,11911$. [CrossRef] [PubMed]

44. Xie, Z.; Wang, G.; Wang, J.; Chen, M.; Peng, Y.; Li, L.; Deng, B.; Chen, S.; Li, W. Synthesis, Biological Evaluation, and Molecular Docking Studies of Novel Isatin-Thiazole Derivatives as $\alpha$-Glucosidase Inhibitors. Molecules 2017, 22, E659. [CrossRef] [PubMed]

45. Zhu, J.; Zhang, B.; Tan, C.; Huang, Q. $\alpha$-Glucosidase Inhibitors: Consistency of in Silico Docking Data with in Vitro Inhibitory Data and Inhibitory Effect Prediction of Quercetin Derivatives. Food Funct. 2019, 10, 6312-6321. [CrossRef] [PubMed]

46. Ting, L.; Xiao-dong, Z.; Yu-wen, S.; Jian-wen, L.I.U. A Microplate-Based Screening Method for Alpha-Glucosidase Inhibitors. Chin. J. Clin. Pharmacol. Ther. 2020, 10, 1128.

47. Wang, G.; Peng, Y.; Xie, Z.; Wang, J.; Chen, M. Synthesis, $\alpha$-Glucosidase Inhibition and Molecular Docking Studies of Novel Thiazolidine-2,4-Dione or Rhodanine Derivatives. Med. Chem. Commun. 2017, 8, 1477-1484. [CrossRef] [PubMed]

48. Frisch, M.; Trucks, G.; Schlegel, H.B.; Scuseria, G.E.; Robb, M.A.; Cheeseman, J.R.; Scalmani, G.; Barone, V.; Mennucci, B.; Petersson, G.A. Gaussian 09, Revision d. 01, Gaussian. Inc. Wallingford CT 2009, 201, 6-10.

49. Dallakyan, S.; Olson, A.J. Small-Molecule Library Screening by Docking with PyRx. In Chemical Biology: Methods and Protocols; Hempel, J.E., Williams, C.H., Hong, C.C., Eds.; Methods in Molecular Biology; Springer: New York, NY, USA, 2015 ; pp. 243-250. ISBN 978-1-4939-2269-7.

50. Trott, O.; Olson, A.J. AutoDock Vina: Improving the Speed and Accuracy of Docking with a New Scoring Function, Efficient Optimization, and Multithreading. J. Comput. Chem. 2010, 31, 455-461. [CrossRef] 